\title{
Re-Examining Government Revenues, Government Spending And Economic Growth In GCC Countries
}

Helmi Hamdi, CERGAM-CAE Aix-Marseille University, France and Central Bank of Bahrain, Kingdom of Bahrain Rashid Sbia, DULBEA, Solvay Brussels School of Economics and Management and ERS, Ministry of Finance, Manama, Kingdom of Bahrain

\begin{abstract}
The aim of this paper is to examine the inter-temporal relationship between government revenues and expenditures within a trivariate framework by modeling them together with gross domestic product. Our sample is based on a panel of 6 countries of the Gulf Cooperation Council (GCC) i.e. Saudi Arabia, Kuwait, United Arab Emirates, Qatar, Oman and Bahrain, for the period from 1990 to 2010. We perform an econometric model based on the Toda and Yamamoto procedure. Our empirical results show that government expenditures Granger cause government revenues for Qatar and the United Arab Emirates only, while government revenues Granger cause government expenditures for Saudi Arabia only. We also found a unidirectional causality running from government expenditures to GDP in Bahrain only. Regarding Kuwait, Qatar and Saudi Arabia, GDP Granger cause government revenues while GDP Granger cause government expenditures for Oman and Qatar.
\end{abstract}

Keywords: Fiscal Policy; GCC; Toda-Yamamoto; Granger Causality

\section{INTRODUCTION}

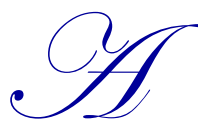

n understanding of the relationship between government spending and revenues is a fundamental insight in assessing the effectiveness of government's strategy in managing its resources. Exploring this relationship is also important to ensure fiscal stability especially during the current period in which the world economy has witnessed the worst crisis since 1929 Great Depression. Indeed, the origin of the current turbulence has been the level of debt which reached a record sign in several developed and developing countries as well ${ }^{1}$. Hence, implementing an efficient fiscal policy is crucial to promote price stability and sustainable economic growth.

Since the pioneering works of David Ricardo (1820) and Adolph Wagner (1893), numerous articles have analyzed the relationship between government revenues and expenditures for different countries. Generally speaking, the debate has received particular attention during the seventies; especially following the $2^{\text {nd }}$ oil shock where fiscal policy has became the hub of economic growth. Since that date, many hypotheses have emerged to describe the relationship between government revenues and expenditures. Those hypotheses can be classified into 4 categories. The first one is the tax-and-spend hypothesis supported by Friedman (1978) and Buchanan and Wagner (1978), which suggests that changes in revenue generate changes in expenditure. The authors advocate that tax raises will necessary lead to expenditure upturns. This hypothesis could be observed as unidirectional causality running from government revenues to government expenditures. The second assumption is the spend-and-tax hypothesis suggested by Peacock and Wiseman (1961, 1979) and Barro (1974) advocates that changes in expenditures induce changes in revenue. The authors introduce the "displacement effect" notion which considers that any significant exogenous troubles like wars and other unstable political events or natural disasters, will

\footnotetext{
${ }^{1}$ In 2010 the debt to income ratio reaches $147.8 \%$ in Greece, $109 \%$ in Italy and $96.8 \%$ in Belgium (OECD 2011).
} 
provoke an increase in government spending and therefore an increase in tax revenues. This hypothesis can be interpreted as unidirectional causality running from government spending to government revenue (Blackley 1986 and Ram 1988). The third hypothesis is fiscal synchronization suggested by Musgrave (1966) and later by Meltzer and Richard (1981). This hypothesis assumes that government optimal fiscal policies rely on voters' decision process outcomes concerning their demand for public services and their reactions toward income redistribution (Miller and Russek 1990; Owoye 1995). In contrast to the previous hypothesis, fiscal synchronization is characterized by bidirectional causality between government revenues and government expenditures. Finally, the forth hypothesis is institutional separation developed by Baghestani and McNown (1994) which considers that government revenue and expenditure are independent from each other. As there is no relationship between government revenue and expenditure, this hypothesis is characterized by non-causality in empirical terms.

Nowadays, due to the sovereign debt crisis and the consequent fiscal turbulence that hit Europe, the debate on the relationship between government revenues and expenditures is becoming a new concern and new priority for policy makers. In fact, the current crisis shows how mismanagement of fiscal policy can threaten the welfare of a country and how crucial effective fiscal policy is for economic development.

The aim of this paper is to examine the relationship between government revenues, government spending and economic growth for Gulf Cooperation Council (GCC) countries for the period from 1990 to 2010. The region is a key player in the global energy market and a new hub of finance and international affairs. Despite the abundance of natural resources (oil and gas) and high oil prices, and thus large revenues, the region has witnessed a critical period in 2008-2009. In fact, the subprime crisis has generated the so called 'Dubai crises'. The later was generated by high expenditures in the real estate sector without taking into account the fluctuation of energy prices and the volatility of the demand for housing. Fiscal policy was ineffective as it depends to oil revenues and the exposure to external shocks was very high. The consequences of the twin crisis have strongly affected the region as a whole and have threatened its position as a hub of finance. Therefore, managing government revenues and expenditures is becoming a sine qua none condition for the survival of the GCC region. To the best of our knowledge the only article which studied fiscal policy in GCC countries is the work of Fasano and Wang (2002). Authors have investigated the nature of the relationship between government expenditures (capital and current expenditures) and non-oil GDP in GCC countries over the period 1980-2000 using vector error correction model. They found bidirectional causality for Kuwait, Qatar and Saudi Arabia. While, for Bahrain, the United Arab Emirates and Oman, a unidirectional causality was found running from revenue to expenditure. However, in their study, Fasano and Wang did not take into consideration government revenue which is an important variable in the case of GCC countries as the management of fiscal policy in these countries is mostly based on oil revenues ${ }^{2}$. Therefore the current study aims to enrich the available literature by the use of a trivariate causality framework to examine the causal relationship between government revenues, government spending and economic growth in GCC countries. The trivariate Granger causality test is based on the Toda-Yamamoto (1995) test, the so-called ModifiedWald test. Moreover, the time series of our study involves the post-financial crisis period, which could give better results and effective policy implications.

\section{DATA AND ECONOMETRIC METHODOLOGY}

This study uses annual real GDP, government spending and government revenues time series data covering the 1990-2010 periods for 6 GCC countries ${ }^{3}$. All the data are taken from the IMF publication International Financial Statistics CD-ROM, and the sample period is common for all countries.

\section{Unit root tests}

We perform an Augmented Dickey-Fuller (ADF) unit root test to test for stationarity of our three variables. The extended maintained regression used in the ADF test can be expressed in its most general form as

\footnotetext{
${ }^{2}$ It is worth to recall that in Bahrain there are no taxes imposed on personal income, wealth or capital gains. Furthermore, there are no death duty taxes or inheritance taxes.

${ }^{3}$ Unfortunately, this is the longest available data series in the IMF's CD-ROM.
} 
follows: $\Delta Y_{t}=\mu+\gamma Y_{t-1}+\sum_{j=1}^{p} \alpha_{j} \Delta Y_{t-j}+\beta t+\omega_{t}$, where $\mu$ is the drift term, $t$ denotes the time trend and $p$ is the largest lag length used. The null hypothesis $\mathrm{H}_{0}: Y_{t}$ is $\mathrm{I}(1)$, that is unit root, is rejected in favor of $\mathrm{I}(0)$ if $\gamma$ is found to be negative and statistically significantly different from zero.

\section{Toda-Yamamoto procedure}

Broadly, Granger causality is used if the underlying series data are stationary and integrated. Toda and Yamamoto (1995) developed a different method that is used to estimate the standard VAR by the use of a Modified Wald test for restrictions on the parameters of the VAR $(k)$ model and then estimates a VAR with $k+d m a x$, where $k$ is the lag order of VAR and dmax is the maximal order of integration for the series in the model. The Toda and Yamamoto technique is easy to process and it does not require knowledge of cointegration properties of the series. This means that the Granger causality test can be done even when there is no cointegration and/or when the stability and rank properties are not fully satisfied (Zapta and Rambaldi, 1997). Following Narayan and Narayan (2006), the trivariate framework can be expressed as follows ${ }^{4}$ :

$$
\begin{aligned}
& \ln G R_{t}=\alpha_{1}+\sum_{i=1}^{k+d \max } \beta_{1 i} \ln G R_{t-i}+\sum_{i=1}^{k+d \max } \beta_{1 i} \ln G E_{t-i}+\sum_{i=1}^{k+d \max } \beta_{1 i} \ln G D P_{t-i}+\mu_{1 t} \\
& \ln G E_{t}=\alpha_{2}+\sum_{i=1}^{k+d \max } \beta_{2 i} \ln G E_{t-i}+\sum_{i=1}^{k+d \max } \beta_{2 i} \ln G R_{t-i}+\sum_{i=1}^{k+d \max } \beta_{2 i} \ln G D P_{t-i}+\mu_{2 t} \\
& \ln G D P_{t}=\alpha_{3}+\sum_{i=1}^{k+d \max } \beta_{3 i} \ln G D P_{t-i}+\sum_{i=1}^{k+d \max } \beta_{3 i} \ln G E_{t-i}+\sum_{i=1}^{k+d \max } \beta_{3 i} \ln G R_{t-i}+\mu_{3 t}
\end{aligned}
$$

Where LGR is the logarithm of real general government revenues, LGE is the logarithm of real general government expenditures; LGDP is the logarithm of real gross domestic product.

Toda-Yamamoto method is performed in two steps. The first one consists in determining the lag length $(k)$ of VAR model and the maximum order of integration $(d)$ of the time series variables in the model. After the selection of optimum lag length VAR $(k)$ and the order of integration dmax, a level VAR is estimated with a total of $[k+d$ max $]$ lags. The second step requests the application of the standard Wald tests on the first $(k)$ VAR coefficient matrix to make Granger causal inference using a chi square $\left(\chi^{2}\right)$ distribution.

\section{EMPIRICAL RESULTS}

Before performing Granger causality procedures it is important to determine the order of integration of the series (dmax) and the optimal lag length $k$, in order to avoid spurious causality or spurious absence of causality (Clark and Mirza, 2006). For the unit root testing, we conduct Augmented Dickey-Fuller tests. The second step is to determine the optimal lag length to identify the true dynamics of the model. To determine optimal lag length of VAR system, the sequential modified LR test statistic (LR), Final prediction error (FPE), Akaike information criterion (AIC), Schwarz information criterion (SC) and Hannan-Quinn information criterion (HQ) lag selection criteria are used. The result of selecting optimal lag length of VAR indicate that lag order of VAR (k) is 2 , for trivariate VAR. the third step is to augment the VAR by the maximum order of integration of the series (dmax) and then test for any misspecification to ensure that the classical regression assumptions were not violated.

\footnotetext{
${ }^{4}$ We adopt the same trivariate framework used by Payne (1997) and Narayan and Narayan (2006). The first author has used the Johansen-Juselius multivariate cointegration procedure and error correction modeling while the second authors have used Toda and Yamamoto procedure.
} 


\section{ADF Unit root test}

The unit root tests have to be performed to test whether variables of the model are stationary or not. For this purpose, an Augmented Dickey-Fuller (ADF) unit root test is carried out on the time series in levels and differenced forms. Table 1 contains the results of the stationarity analysis. The results show that we cannot reject the null hypothesis of unit roots for all variables in level forms. However, the null hypothesis is rejected when the ADF test is applied to the first differences of each variable. The first differences of the lnGDP, lnGR and lnGE, are stationary indicating that these variables are in fact integrated of order one, $I(1)$.

\begin{tabular}{|c|c|c|c|c|c|c|c|c|c|c|c|c|}
\hline \multirow[t]{2}{*}{ Variables } & \multicolumn{2}{|c|}{ Bahrain } & \multicolumn{2}{|c|}{ Kuwait } & \multicolumn{2}{|c|}{ Oman } & \multicolumn{2}{|c|}{ Qatar } & \multicolumn{2}{|c|}{ Saudi Arabia } & \multicolumn{2}{|c|}{ UAE } \\
\hline & Level & 1stdiff & Level & 1stdiff & Level & 1stdiff & Level & 1stdiff & Level & 1stdiff & Level & 1stdiff \\
\hline LGR & -3.14 & $-4.62 * * *$ & -2.55 & $-4.29 * * *$ & $-3.49 *$ & $-5.55 * * *$ & -0.15 & $-4.30 * *$ & -2.94 & $-5.97 * * *$ & -1.99 & $-4.55 * * *$ \\
\hline LGE & $-3.38 * *$ & $-5.97 * * *$ & -1.51 & $-6.59 * * *$ & 0.08 & $-3.09 * *$ & 0.08 & $-3.09 * *$ & -2.09 & $-5.29 * * *$ & -0.78 & $-3.67 * *$ \\
\hline LGDP & $-4.05 * *$ & $-4.68 * * *$ & $-5.08 * * *$ & $-2.85^{*}$ & -0.86 & $-3.02 * *$ & -0.86 & $-3.01 *$ & -1.55 & $-4.39 * * *$ & -2.34 & $-3.56 * *$ \\
\hline
\end{tabular}

\section{Toda and Yamamato Granger causality tests}

In order to examine the direction of causality we apply the Toda and Yamamato (1995) technique which, as mentioned above, provides valid inference in the context of unstable, possibly cointegrated systems. The results of these tests are presented in Table2.

\begin{tabular}{|l|c|c|c|c|c|c|}
\multicolumn{9}{|c}{ Table 2. Toda-Yamamoto Granger causality } \\
\hline & Bahrain & Kuwait & Oman & Qatar & Saudi Arabia & UAE \\
\hline GE $=>$ GR & 0.2447 & 0.1714 & 2.3607 & $8.1504 *$ & 1.0234 & 9.6229 \\
& $(0.8848)$ & $(0.9179)$ & $(0.5010)$ & $(0.0862)$ & $(0.3117)$ & $(0.0221)^{* *}$ \\
\hline GDP => GR & 0.2464 & 6.8787 & 5.2316 & 18.759 & 5.9196 & 5.9459 \\
& $(0.8841)$ & $(0.0087)^{* * *}$ & $(0.1556)$ & $(0.0009)^{* * *}$ & $(0.0150)^{* *}$ & $(0.1143)$ \\
\hline GR $=>$ GE & 0.7909 & 0.6865 & 3.5534 & 4.0648 & $6.5482^{*}$ & 1.5101 \\
& $(0.6734)$ & $(0.7095)$ & $(0.3139)$ & $(0.2546)$ & $(0.09134)$ & $(0.6799)$ \\
\hline GDP => GE & 1.9991 & 0.9737 & 28.377 & 6.7283 & 0.0081 & 1.6563 \\
& $(0.3680)$ & $(0.6146)$ & $(0.0000)^{* * *}$ & $(0.0811)^{*}$ & $(0.9282)$ & $(0.6467)$ \\
\hline GR => GDP & 1.2829 & 0.7216 & 3.0686 & 5.1283 & 1.7668 & 3.0097 \\
& $(0.5265)$ & $(0.6971)$ & $(0.3812)$ & $(0.1626)$ & $(0.1838)$ & $(0.3901)$ \\
\hline GE $=>$ GDP & 8.8135 & 0.0759 & 0.5937 & 2.0912 & 0.8139 & 2.7644 \\
& $(0.0122)^{* *}$ & $(0.9627)$ & $(0.8979)$ & $(0.5537)$ & $(0.3670)$ & $(0.4294)$ \\
\hline $\boldsymbol{P = k + d m a x}$ & $(3)$ & $(2)$ & $(4)$ & $(5)$ & $(2)$ & $(4)$ \\
\hline
\end{tabular}

$* * *, * *$ and $*$, denote significant levels at 1\%, 5\% and $10 \%$ respectively.

The results of Granger non-causality test due to Toda and Yamamoto (1995) procedure are displayed in table 2 and can be summarized as follows. First, despite the similarities of the 6 GCC countries, the results are not identical. Second, there is no bidirectional relationship between the different variables for any country. Furthermore, results show that there is no causal relationship running from revenue to expenditures, except for Saudi Arabia, which is incompatible with the 'fiscal synchronization hypothesis'. This implies that revenues and expenditures decisions are made independently in the 5 other countries of the GCC. Meanwhile, for the United Arab Emirates and Qatar causality runs from government expenditures to government revenues, supporting the spend-and-tax hypothesis. For Oman and Qatar, there is unidirectional causal relationship running from GDP to government expenditures while a unidirectional causal relationship exists running from GDP to government revenues for Kuwait, Qatar and Saudi Arabia. Bahrain is the only country in which causality runs from government expenditures to GDP. Here again, we can see a huge heterogeneity between GCC countries. Our conclusion is that fiscal policy may change from one country to another one despite the similarity between them.

\section{CONCLUSION}

Since the Greece and the European sovereign debt crisis, the relationship between government expenditures and government revenues is becoming the most important concern in macroeconomics. Several developing and developing countries have been experiencing government budget deficits and policy makers are now looking for sustainable economic growth by controlling expenditures and public debts. Since last few years, GCC countries 
have increased significantly their government expenditures in many socioeconomic sectors thanks to the high energy prices. The surge in oil prices has provided such a large earnings windfall has bolstered the fiscal position of the GCC countries. However, when oil prices became volatile, fiscal policy needs to be implemented effectively to avoid fiscal unbalances. This study has employed the Toda and Yamamoto (1995) procedure to determine the Granger no-causality test between government revenues, government expenditures and growth for GCC countries. The tests are based upon annual time series for the period of 1990-2010. Toda and Yamamoto model indicates that government expenditures Granger cause government revenues for Qatar and the United Arab Emirates only. Hence, there is no evidence for spend-and-tax hypothesis for 4 countries of our sample. Moreover, government revenues Granger cause government expenditures for Saudi Arabia only. Therefore, there is no evidence for tax-and-spend hypothesis for 5 countries of our sample. We also found a unidirectional causality running from government expenditures to GDP in Bahrain only. For Kuwait, Qatar and Saudi Arabia, GDP Granger causes government revenues while GDP Granger causes government expenditures for Oman and Qatar.

\section{AUTHOR INFORMATION}

Helmi Hamdi, Senior Economist at the Central Bank of Bahrain and senior research fellow at CERGAM-CAE AixMarseille University. E-mail: helmi_aix@yahoo.fr (Corresponding author)

Rashid Sbia, Senior Economist at ERS Ministry of Finance Bahrain and research fellow DULBEA, Solvay Brussels School of Economics and Management, Brussels Belgium.

\section{REFERENCES}

1. Baghestani, H., McNown, R., (1994). Do Revenues or Expenditures Respond To Budgetary Disequilibria? Southern Economic Journal, 61, (2), 311-322.

2. Barro, R.J., (1978). On the Determination of the Public Debt; Journal of Political Economy; 81, 940-971.

3. Blackley, P.R., (1986). Causality between revenues and expenditures and the size of the federal budget. Public Finance Quarterly, 139-56.

4. Buchanan J.M., Wagner, R.W., 1978). Dialogues concerning Fiscal Religion; Journal of Monetary Economics, 4,627-636

5. Clark, J., Mirza, S.A., (2006). Comparison of some common methods of detecting Granger noncausality. Journal of Statistical Computation and Simulation 76, 207-231.

6. Fasano, U., Wang, Q., (2002). Testing the Relationship Between Government Spending and Revenue: Evidence from GCC Countries. IMF Working Paper WP/02/201.

7. Friedman, M., (1978). The Limitation of Tax Limitation. Policy Review, 7-14.

8. Furstenberg, V., Green, R.J., Jeong, J., (1986). Tax and spend, or spend and tax?. Review of Economics and Statistics, 179-88.

9. Jones, J.D., Joulfain, D., (1991). Federal Government Expenditures and Revenues in the Early Years of the American Republic: Evidence from 1792-1860. Journal of Macroeconomics, 13, (1), 133-155.

10. Miller, S.M., Russek, F.S., (1990). Co-integration and error correction models: temporal causality between government taxes and spending. Southern Economic Journal, 33-51.

11. Musgrave, R., (1966). Principles of Budget Determination. H. Cameron and W. Henderson (eds.), Public Finance Selected Reading. New York: Random House. 15-27.

12. Narayan, P.K. \& Narayan, S., (2006). Government Revenue and Government Expenditure Nexus: Evidence from Developing Countries, Applied Economic, 38, 285-291.

13. Owoye, O., (1995). The Causal Relational Between Taxes and Expenditures in the G7 countries: Cointegration and Error-correction Models. Applied Economics, 2, (1), 19-22.

14. OECD, 2011). Central Government Debt, OECD National Accounts Statistics (database). OECD

15. Payne, J. E. (1997), The tax-spend debate: the case of Canada, Applied Economics Letters, 4, 381-86.

16. Peacock, A., Wiseman, J., (1979). Approaches to the Analysis of Government Expenditure Growth. Public Finance Review, 7, 3-23.

17. Ram, R., (1988). Additional Evidence on Causality Between Government Revenue and Government Expenditure. Southern Economic Journal, 54, 763-769. 
18. Ricardo, D., (1820). "Funding System", in The Works and Correspondence of David Ricardo, Sraffa, P. (ed.) (1951), Cambridge University Press, Cambridge.

19. Toda, H.Y., Yamamoto, T., 1995). Statistical inference in vector autoregression with possibly integrated process. Journal of Econometrics, 66, 225-250.

20. Wagner, A. (1893) Grundlegung der politischen Okonomie. Leipzig: C. F. Winter.

21. Zapata, H.O., Rambaldi, A.N., 1997. Monte Carlo evidence on cointegration and causation. Oxford Bulletin of Economics and Statistics 9, 285-298. 